\title{
The Evaluation of Primary School Teacher Role on Research Activities
}

\author{
Akhatayeva Ulsana Borashkyzy ${ }^{1 *}$, Amirova Amina1, Sydykova Zukhra Eshtayevna², Karabayeva Kulzariya Userkhanovna³, \\ Dauletaliyeva Dinara Myktybaevna ${ }^{4}$, Bulshekbayeva Assem Issaevna ${ }^{5}$
}

${ }^{1}$ Institute of Pedagogy and Psychology, Department of Pedagogy and Methods of primary education, KazNPU named after Abai, Dostyk ave., Almaty, Kazakhstan, e-mail: ulsana_a@mail.ru; amirova57@mail.ru

${ }^{2}$ Chair of Pedagogy, Faculty of Economics and Pedagogy, International Humanitarian and Technical University, Shymkent, Kazakhstan, e-mail: zuhra0007@mail.ru

${ }^{3}$ Chair of History of Kazakhstan and Law Faculty of Economics and pedagogy, International Humanitarian and

Technical University, Shymkent, Kazakhstan, e-mail: kulzaria@gmail.com

${ }^{4}$ Chair of Pedagogy and Psychology, Faculty of Humanities and Pedagogy, University named after academician

A.Kuatbekov, Shymkent, Kazakhstan, e-mail: dauletalieva_1984@mail.ru

${ }^{5}$ Department of preschool education and social pedagogy, KazNPU named after Abai, Dostyk ave., Almaty,

Kazakhstan, e-mail: bulshekbaeva@mail.ru

\begin{abstract}
Many primary education programs, including the updated educational program in Kazakhstan, involve the creation and implementation of thematic units to prepare younger students for research activities. This approach is reflected in the integrated method of teaching and learning in primary classes. However, in cases where the research-based pedagogical approach is not used, it has become an urgent problem because it cannot meet the interest of students. Therefore, this article intends to study theoretical works on the preparation of primary school students for research, conduct experimental work on a small experimental site, and consider specific results. In theoretical terms, such works as content analysis, synthesis, generalization, survey, and diagnostics were organized. Analyzing the experimental work on the stages of identification and formation. Based on methodological materials to prepare students for research, we offer percentages.
\end{abstract}

Keywords: cognitive research, collective design, research activities, research algorithm, research-based learning, selfreflective research.

\section{Introduction}

In today's closely interconnected and multicultural world, it is important to develop self-learning skills of students to be accompanied by a dynamic pace of progress of the XXI century. The concept of scientific research, world views are formed in the interaction of students. The activity of joint research contributes to the formation of interaction and communicative communication, the development of creative opportunities, setting research goals (Roth, 2014), is used as a psychological basis in the educational process, as a guiding theory that provides great help to teachers. In the educational process, it is especially necessary to form synthesis, abstract, representative, generalizing, generalizing, systematizing, mental operations. Based on the psychological theory of activity of Talyzina (1975) created the theory of the formation stages of the motor action of the mind. He demonstrated the basics of three types of actions. The first is an incomplete action, which consists mainly of multiple errors and difficulties, the second type is based on minor additions, and the third takes place in its own very completely, based on actions.

In the process of interaction, data were obtained indicating the effectiveness of the study: they contribute to the formation of interaction and communication relations, self-regulation of students, the development of creative opportunities, setting research goals.

We show that the components of effective communication in the process of research activities develop communicative competence of students:

1. Creative nature of educational tasks,

2. Use in educational activities of personal experience of students, their own thoughts, concepts, and fantasies,

3. The content of the discipline (discipline of the humanitarian cycle),

4. Training system based on the principles of dialogical, open communication,

*Corresponding author: ulsana_a@mail.ru 

process

5. Change of forms of interaction and interaction between the participants of the educational

6. Focus on expanding students ' initiative and their choice of learning goals and objectives.

A special influence on the development of personality has a creative nature of educational tasks. The introduction of creative tasks in the learning process at school-is a new direction in the search for new forms of education that are aimed at the creative development of the individual. The inclusion of the context of meaning and goals of students in educational activities is impossible without taking into account their personal experience, needs and interests. If education is not transformed on the basis of subjective experience, it will never matter to the student's personality (Read, 2020).

The state of effective communication provides many opportunities for use in the process of solving creative problems of individual, subjective experience of students (the Fund of their thoughts, concepts and fantasies). This allows for the independence of each student and ensures that students have access to learning activities with individual principles and values .

For the "change" of the meaning of the activity, the system of educational interaction acts as a successor. It is particularly important that the relationship between the participants of the educational process was open, reliable, as open dialogue contributes to the development of communicative competences of students. Another factor in the development of communicative competences in the conditions of open dialogical communication and interaction between the participants of the educational process (teacher, student) is the openness of dialogical communication and cooperation.

\section{Materials and Methods}

The study was conducted employing document analysis and related content analysis among the qualitative research methodology. The basic process in content analysis is to compile similar data within the framework of specified concepts and themes and interpret them organized in a way that readers can understand (Yildirim and Şimşek, 2008). Content analysis method reveals what kind of studies are done in which fields. To support these studies, an experimental study was conducted in a school in Almaty.

The experimental work was conducted in three stages, which included identification, formulation, final experiments in educational institutions identified as research bases. During the identification period, the aim was to determine the role of pupils and teachers in their research activities, their level of assessment, cognitive group research, collective research, prospects for collaborative and business communication. At the same time, questionnaires, tests were conducted to determine the peculiarities of pupils, the nature of their relationships and their relationships, their attitudes towards group, collective, dialogue, emotional relationships, and ability to communicate. These tests allowed the participants to prepare for work in the group, identify psychological barriers, and determine the direction of work on their correction. 


\section{Results}

\section{Directions of research idea}

Table 1

Directions of research idea

\begin{tabular}{|c|c|c|}
\hline $\begin{array}{c}\text { Author } \\
1\end{array}$ & $\begin{array}{c}\text { Definition } \\
2 \\
\end{array}$ & $\begin{array}{c}\text { The main idea } \\
3\end{array}$ \\
\hline Pirogov, N.I. & $\begin{array}{l}\text { «There are elements of moral education in } \\
\text { science that do not lose their importance. } \\
\text { Pay and science, influencing the position } \\
\text { of trainee reaches its achieved» }\end{array}$ & $\begin{array}{l}\text { The tutor knew that the Sciences } \\
\text { had a pupil in their heart. } \\
\text { "Self-service is not only at the hands } \\
\text { of someone, but also teaches this in } \\
\text { our schools." }\end{array}$ \\
\hline Ushinsky, K.D. & $\begin{array}{l}\text { «lt is necessary to teach a person to use } \\
\text { this treasure, enriching knowledge» }\end{array}$ & $\begin{array}{l}\text { Everyone has to be self-centered, } \\
\text { and only when he learns to acquire } \\
\text { this knowledge. }\end{array}$ \\
\hline Vakhterov, V. P. & $\begin{array}{l}\text { «Learners should find and find out the } \\
\text { facts and think through scientific research } \\
\text { methods» }\end{array}$ & $\begin{array}{l}\text { Delivery of students to the position } \\
\text { of researchers }\end{array}$ \\
\hline Vsesvyatsky, B.V. & $\begin{array}{l}\text { «Tool for Rebuilding the Rational Thinking } \\
\text { System in the Context of Combat } \\
\text { Problems to Change Life» }\end{array}$ & Research is related to work \\
\hline Raikov, B.E. & $\begin{array}{l}\text { «An effective factor that stimulates } \\
\text { mentality and discipline» }\end{array}$ & $\begin{array}{l}\text { Ability to make the student's own } \\
\text { conclusions }\end{array}$ \\
\hline Yagodovsky, K.P. & $\begin{array}{l}\text { «A pupil's well-documented credentials or } \\
\text { comparative analysis of some facts» }\end{array}$ & $\begin{array}{l}\text { Creating a new formulation of the } \\
\text { student }\end{array}$ \\
\hline Lerner, I. Ya., Skatkin, M. N. & "The way of activity and self-development" & Formation of creative activity \\
\hline Makarenko, A. S. & Pedagogical tool & «Student cognitive activity» \\
\hline Davydov, V. V. & $\begin{array}{l}\text { «The Living System of Research } \\
\text { Thoughts» }\end{array}$ & $\begin{array}{l}\text { 《... the content and comprehensive } \\
\text { disclosure of the training material } \\
\text { must be consistent with the results } \\
\text { of the research» }\end{array}$ \\
\hline Khutorskoy, A.V. & $\begin{array}{l}\text { organized action of a student to } \\
\text { communicate with the environment and } \\
\text { himself }\end{array}$ & «Learning through action» \\
\hline
\end{tabular}

It was found out that the factors influencing the formation of competencies during the study of pupils are: the creative nature of the research assignments, to analyze personal experience of students, to develop their own thoughts, ideas and fantasies, dialogue, open-minded expression, joint discussion, selection and execution of interesting tasks.

According to the theoretical research, primary schooling provides for the development of pupils at the expense of: providing opportunities for the development of research skills; actively develop skills to analyze and critically analyze any information received; self-reflection and independent, self-motivating thinking; understand and respond to major global challenges that occur in everyday life or at work. By studying the subjects taught in elementary grades, learners are expected to be responsible for their ideas by expanding their understanding (Turalbayeva et al., 2017).

Learners acquire the skills to build and develop their own thinking and judgment, carefully study and convincingly express their own ideas. For example, they learn to analyze and evaluate arguments and to think about thinking skills. They will also learn to use information efficiently through interdisciplinary communication. 


\section{Research algorithm}

\section{Table 2}

Research algorithm

\begin{tabular}{|c|c|c|}
\hline Stages & The main theme of the exercises & Types of questions \\
\hline \multirow[t]{2}{*}{ Correct } & Allow students to work with themes. & What is the theme? \\
\hline & Identify issues that the students are interested in. & Why study this topic? \\
\hline \multirow[t]{3}{*}{ Preparing for the study } & Identify what is already known for this topic. & What do we know about this topic? \\
\hline & Identify the direction and form of work for students. & What do you think about this topic? \\
\hline & $\begin{array}{l}\text { Help you plan the workouts and exercises that you } \\
\text { have to do on the topic. }\end{array}$ & $\begin{array}{l}\text { Who else has convinced this? What } \\
\text { do you think? }\end{array}$ \\
\hline \multirow[t]{6}{*}{ Research } & Further motivation of students to education. & What do we really want to know? \\
\hline & Providing new information that will give you an answer & What is the best way to do this? \\
\hline & to your questions. & How do we collect information? \\
\hline & Other questions to consider in the future. & \\
\hline & $\begin{array}{l}\text { Check students' knowledge, values and } \\
\text { understanding. }\end{array}$ & \\
\hline & $\begin{array}{l}\text { Help students to understand future exercises and work } \\
\text { done. }\end{array}$ & \\
\hline \multirow[t]{3}{*}{ Sort by } & Provide learners with specific ways of sorting and & How can we sort the information? \\
\hline & $\begin{array}{l}\text { presenting information and ideas identified during the } \\
\text { «research» period. }\end{array}$ & $\begin{array}{l}\text { What kind of communication can we } \\
\text { make? }\end{array}$ \\
\hline & $\begin{array}{l}\text { Allow students to process and process information in } \\
\text { a variety of ways. } \\
\text { Allowing a wide range of results. }\end{array}$ & $\begin{array}{l}\text { How can we make sure that the } \\
\text { information is accurate, valuable, } \\
\text { and available? }\end{array}$ \\
\hline \multirow[t]{2}{*}{ Progress ahead } & $\begin{array}{l}\text { Expand the themes and check the pupils' } \\
\text { understanding of the topic. } \\
\text { Provide more information to help pupils expand their }\end{array}$ & $\begin{array}{l}\text { What are the conclusions we have } \\
\text { reached? What are some of the } \\
\text { facts that we can justify? }\end{array}$ \\
\hline & scope of ideas. & $\begin{array}{l}\text { What do we do with the results? } \\
\text { What can we do? }\end{array}$ \\
\hline \multirow[t]{2}{*}{ Contact setup } & $\begin{array}{l}\text { Help students make conclusions about what they } \\
\text { learned. }\end{array}$ & $\begin{array}{l}\text { What did we conclude? What are } \\
\text { some of the facts that we can }\end{array}$ \\
\hline & $\begin{array}{l}\text { Allow the reflection of the learning process and its } \\
\text { learning. }\end{array}$ & $\begin{array}{l}\text { justify? } \\
\text { What do we do with the results? }\end{array}$ \\
\hline Take action & $\begin{array}{l}\text { Help students connect with their concept and life } \\
\text { experience. }\end{array}$ & $\begin{array}{l}\text { What can we do? What do you think } \\
\text { about the topic now? }\end{array}$ \\
\hline
\end{tabular}

Deep learning depends on the skills of the teachers, so it is important for students to control their new knowledge with their previous knowledge. This process differs depending on the individual skills and abilities of each student. For this reason, teachers need to regularly assess individual students to help them identify and follow the next steps of the learning process.

Relationships with these terms will be as follows: expanding the student's research services, replacing the role of the performer with the role of the organizer, and creating the conditions for selffulfillment of certain actions. The organization of students' research activities consists of stages such as reflexive analysis, modification of their own behavior, continuous improvement of themselves and stabilization of the reflection need, and because of which the structure of the person's communicative competence is formed.

An experiment was conducted to identify and analyze the situation in the content of these terms in the organization of students' research activities with experimental schools in Almaty. Students and teachers were interviewed and analyzed.

Thus, we can define, "basis for the preparation of pupils to research activities is through selfreflection research, cognitive research and periodic organization of collective-design studies."

Their formation is carried out based on relations established as pedagogical conditions. It can be described as the following pedagogical-psychological structure.

An important factor of student development is not only the level of their knowledge and skills, but also the system of teaching methods and tools used by the teacher to set up the entire learning process, which enables them to formulate mentally healthy activities. The teacher is thoroughly studying the diverse motives of his pupils and leads to the formation of stable motives for continuous education, self-discipline. Interactive methods play an important role in educating cognitive motivations within the 
learning motives. Cognitive activity indicates that learning becomes easier, freer, more persistent, and more productive. Cognitive enthusiasm moves to cognitive necessity.

Work with the group allows students to solve several tasks simultaneously. The main thing - it develops communicative skills and competences, helps to establish emotional connection among schoolchildren, and educates them as it teaches teamwork and takes into account the opinions of their peers. At the same time, the use of the group during the lesson, as practice shows, will reduce the burden on the pupils, change their behavior, focus on the main subject matter.

\section{Stages of teacher and student training in research activities}

\section{Table 3}

Stages of teacher and student training in research activities

\begin{tabular}{|c|c|}
\hline Stages of action & The content of action \\
\hline 1. Goal and motivation. Defining the subject and purpose & Learner: Analyze, search, gathering of different information. \\
\hline of the project. & Teacher: to give his idea, motivation, help in setting tasks. \\
\hline 2. Formation of Concept: & Learner: sets tasks and creates an action plan. \\
\hline $\begin{array}{l}\text { A) creation of base model on the basis of accumulated } \\
\text { data. }\end{array}$ & Teacher: corrects, offers ideas, talks about the game. \\
\hline \multicolumn{2}{|l|}{ B) Formation of concepts. } \\
\hline \multicolumn{2}{|l|}{ C) presenting their ideas } \\
\hline \multirow{2}{*}{$\begin{array}{l}\text { 3. Information collection (control, work with literature, } \\
\text { questionnaire, experiment, etc.) }\end{array}$} & Learner: collects information. \\
\hline & $\begin{array}{l}\text { Teacher: controls, defines the general situation, manages } \\
\text { the activity indirectly. }\end{array}$ \\
\hline \multirow[t]{2}{*}{ 4. Information analysis, conclusions. } & Learner: analyzes information. \\
\hline & Teacher: corrects, monitors, advises. \\
\hline $\begin{array}{l}\text { 5. Collective analysis and evaluation of results (oral and } \\
\text { written report, assessment of the results of the research on } \\
\text { the criteria set out) }\end{array}$ & $\begin{array}{l}\text { Learners and teachers participate in collective bargaining, } \\
\text { evaluate and use unused opportunities, creativity, and } \\
\text { effectively utilize various auxiliary tools such as technical } \\
\text { means, visual aids, and quality of reports. }\end{array}$ \\
\hline
\end{tabular}

The determination of the findings of the experiment demonstrated the low effectiveness of the content of the communication described in these terms. $59.3 \%$ of teachers in the control group, $64.5 \%$ of teachers in the experimental group, $52.4 \%$ of students in the control group, $49.3 \%$ of students in the experimental group were subjects of the subject, collective-dialogue, personal-reflex relationship low.

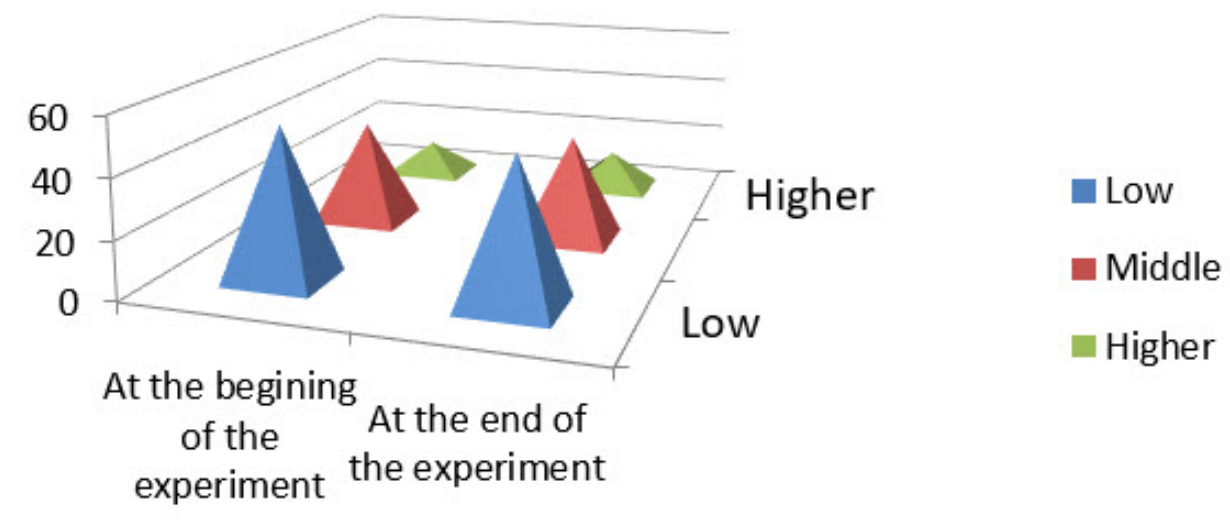

Figure 1. Chart of interest rates at the beginning and end of experimental group control group

It can be observed that the interest rates of participants to the experimental group remained the same as it was at the beginning of the experiment. This shows that there was no difference in interest of the experimental group, which puts them at the same level with the control group. 


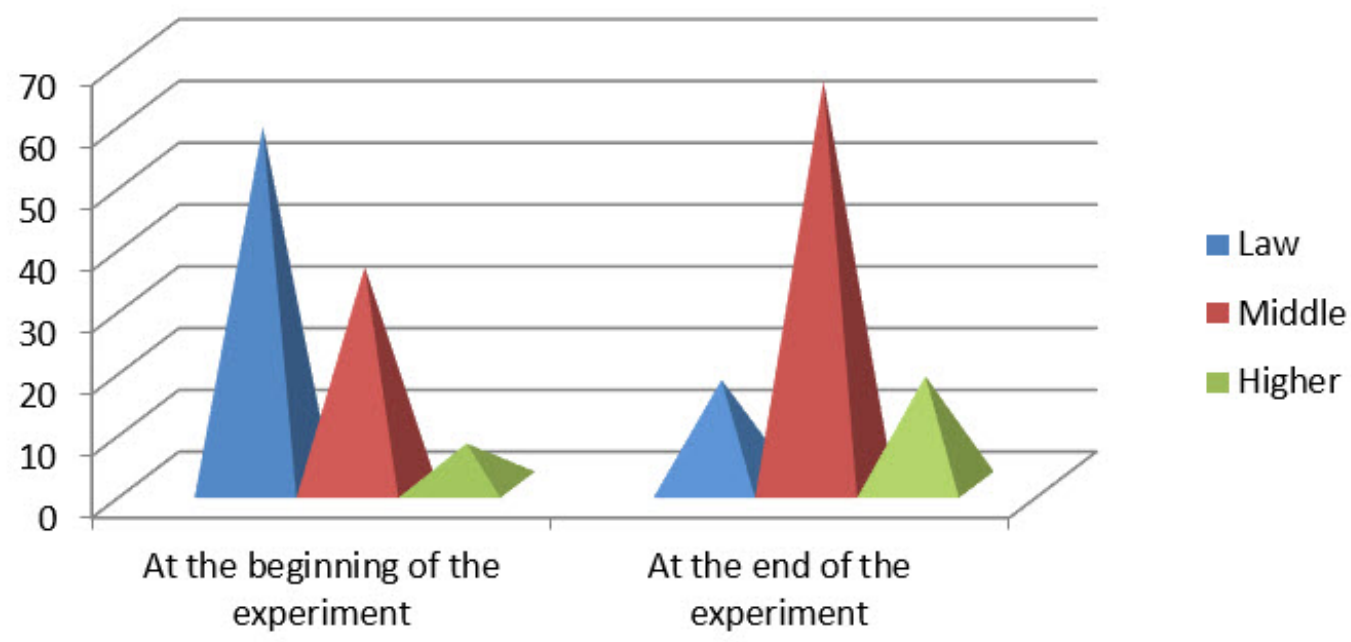

Figure 2. Chart of Experimental Group's Percentage Indicators at the Beginning and end of experiment

The results of this period are defined by the pedagogical conditions of research activities, methods and effective ways of introduction into practice, their types and methods and expected results are determined. The formation of mutual communicative competence according to our pedagogical conditions in our model has revealed that the student needs to expand research possibilities, to change the task role of the role of the organizer, to create the conditions for self-fulfillment of certain actions. As a result of the experimental study of the possibilities for the formation of communicative competence of students, it has been established that they can arrange their thoughts in a free manner, use additional tools to interpret the problem in oral and written form, adapt to group communication, actively engage in dialogue and discussion through their research activities. Practical works include personal records based on oral and written communication of students, ten publications, participation in discussions, open discussions, free microphones, aquariums, etc. communicative trainings were used. It is consistent with other studies (Turculet and Voinea, 2019).

The organization of student research activities is primarily consistent with its own reflection analysis, modification of its own actions, constant improvement of itself and stabilization of the reflection need, and as a result of it is proved that the structure of the person's communicative competence is formed.

At the stage of experimental experiment, design activities were organized to enable students to engage in research activities, develop their own skills, participate in group cognitive research, and collaborate in teamwork. The interactive method includes a wide range of goals and types of communication. Whatever method you use, the main source of knowledge is in the human experience. In the educational process, students communicate with the following people: Teacher (when students answer teacher's question); invited persons (representatives of other organizations, etc.); other students (pair work); small group (3-5 students); Greater group (mostly role-playing games, debates, class discussions, etc.); group of students and the public (the group receives social inquiries); some types of equipment (eg, tablet, smartphone); quantitative composition of the group does not mean the quality of interaction or learning. The main feature of the method of "interrelationship" is the process of disclosure (self-realization), the main purpose of which is the acquisition of learning skills through interactions.

In our work, the active use of the research method has proved that education in the process of interaction is effective. Learners can quickly learn and discuss what they have learned during the exchange, which is due to the following reasons: Students can reasonably explain that the information is not merely the information but the way to find a solution and the correctness of the solution or the best of the proposed variants and proves their point of view; knowing that ill-founded solutions cause conflicts, students will deeply discuss their ideas; students use their own and others' experiences to solve the problem; the teacher can also learn some things from the learners.

Privileged or small-group relationships:

- Students can share with their peers in small groups, in which they cannot speak in groups or only with their teachers.

- Learners know that there are other good ideas than their own. 
Description of the interactive teaching method:

- Students are active for a long time, discuss and execute the task.

- Forms the skill.

- The teacher will help, control and ask questions during the debate. Teacher is a guide.

- The life experience of pupils is important.

- Interaction.

- In the majority of trainings, pupils are looking for answers to the question.

- Work in pairs and groups.

- New types of evaluation.

During the course of the following actions:

- Theoretical questions for students are discussed.

- The teacher organizes work according to the task, motivates students to cognitive activity.

- The teacher teaches students to draw conclusions based on their own opinions.

We will focus on some of the techniques of business game that we use in our experiments to develop oral and written communication skills.

Interview. Students who enter into communication are divided into pairs. One member of the pair will be the "interviewer" and the second member will be "Interverse". 30-minute interviews, or interviewing, and then 20 minutes for group analysis.

The Big Circle method can be used if the solution is to be found quickly. With it, you can create research guides and project themes, guide for researchers. The work consists of three stages:

- The band is sitting in a large circle. A student or a teacher presents a problematic issue.

- Each student within a certain time (10 minutes) writes his / her suggestions on the paper.

- Each student presents their proposals on the circle; the group listens to these suggestions without exception and adds to the board decision on joining and voting.

Table 4

Beginner's and end-of-life indicators for levels of student readiness

\begin{tabular}{|c|c|c|c|c|c|c|}
\hline \multirow{3}{*}{ Stages } & \multicolumn{6}{|c|}{ Percentage of pupils preparing for research activity (\%) } \\
\hline & \multicolumn{3}{|c|}{$\begin{array}{l}\text { Control } \\
\text { Group }\end{array}$} & \multicolumn{3}{|c|}{$\begin{array}{c}\text { Experimental } \\
\text { group }\end{array}$} \\
\hline & Law & Middle & Higher & Law & Middle & Higher \\
\hline At the beginning of the experiment & 52,0 & 36,0 & 12 & 58 & 35,3 & 6,7 \\
\hline At the end of the experiment & 49,3 & 37,0 & 13,7 & 17 & 65,4 & 17,6 \\
\hline
\end{tabular}

This will create a favorable environment for the formation and development of spoken and written communicative competences of students involved in research activities. As a result of experimental work, positive outcomes of students' research activities, in particular communication skills, communication skills, speech and writing culture, and their ability to use them in different situations emerged. The result of the research is supported by another research.

\section{Discussion}

The research approach to analysis of psychological, pedagogical and didactic literature, analysis and controlling pedagogical practice implements the influence of education through its essential features and its main function. They reveal the qualities of a socially active student: to discover the new knowledge values of the reader with the study material; creating conditions for creative, scientific and educational activities and active development of students in the educational process; analyze and discuss issues that are socially oriented; organization of educational work and coordination of educational work in various forms; the balance of teaching and out-of-class work in the new qualitative level - pedagogical influence on the development of cognitive autonomy by increasing their unity through creative and scientific knowledge.

As these relationships are reflected on their own cognitive and project relationships in collective research activities, we have organizational-pedagogical terms called 'organizing self-reflection research', 'organization of cognitive research', 'organization of collective-design studies' in the organization of student research activities that should be considered.

In the research activity of students, the person is the subject of his own development and education 
is based on fulfillment of the conditions of self-reflection research (Komensky as seen in Nefedchenko, 2018; Khusainova et al., 2020; Akoul, Lotfi and Radid, 2020). Its essence is to establish a reflection relationship that is the basis for the person to consider himself as valuable: to think with the thoughts, purposes, problems of the deceiver. Self-development as a physical person, separating from the parents, from the teacher to their own world, recognizing their potential, feeling the importance of their souls. The development of the individual's own qualities reflects the need for self-reflection to form it as a subject of its own activity. From the point of view of psychological psychology, reflection is characterized by a revision of the entity's own behavior, its relation to the surrounding by a critical approach to its experience. According to Ozcan and Genc (2016), management through reflection is aimed at developing self-management skills of pedagogical process actors, increasing their responsibility for effectiveness (cognitive, educational, communicative, etc.).

The terms of collective and project research in research activities are applied both to teachers' staff and to the classroom, school staff and administrative groups of pupils. Whichever collective it is, it is based on the ratio of subjects in it (interactions). Therefore, through dialogue with a certain social group, moral and spiritual qualities of a person are formed (Petrovsky, 1996). Until recently, the psychological essence of the individual has been objectively reviewed in relation to the phenomena surrounding it, with little attention paid to the subjective qualities of its emotional impulse.

Man's humanity opens up for himself and for others only in interactions between man and man (Bakhtin, 1979). In his opinion, dialogue is not only a tool for the formation of a personality, but also his human personality. The basis of goodness is how the dialogues in collective action are taken, the activity of a person, the desire to develop on his own, not in the absence of others, but in the intercourse with other people. They provide a dialogue in the service of pupils and teachers: collaboration with other people, understanding and cohesion through joint creative work through collective reflection.

The content of the terms of the organization of cognitive research is the formation of the attitude of the person as a subject of cognitive activity: self-cognition, identification of own needs, the use of their ability based on reflective needs. The content of the communicative competence development through research activities involves the continuous improvement of personality, collective and reflection based on moral and spiritual values. Therefore, we have defined the content of concrete actions of pedagogical management based on personal-oriented technology as follows: Organization of self-reflection researches; an incentive to achieve it by predicting certain research findings; ability to clearly identify deficiencies, identify ways to eliminate them through reflection in the test, student, parental reflex; self-development and learning prepared by the research; a clear understanding of their needs; dissatisfaction with their results; motivation of students to check knowledge and self-examination on their subject.

Activity: work relocation, speech, writing, listening, drawing, etc. and effective methods of primary school pupils' research: brainstorming, design, aquarium, finding important, chains, compositions, roleplaying, debate, work with small groups, work with pairs, etc. was based on experimental work. Ryndak and Saldaeva (2019) were convinced that in the educational process, students and teachers were able to interact and exchange new information. After all, the use of research methods in teaching is achieved through communication between a teacher and a student, a teacher and a small group, a small group and a student. Here, the teacher acts as a moderator. In addition, this interactive learning technology has precise predictive goals. One of them is the creation of a situation in which the learning process is successful, that allows the student to realize his / her level of knowledge in the process of education, to reveal his / her intellectual ability.

When using research activities, specific targeting requirements must be met. The teacher should be fully convinced that students are prepared to work with the group, understanding the purpose and meaning of individual or group work. At the same time, it is necessary to calculate the specific features of the team and organize them in accordance with the level of preparedness for joint research. It is important to be able to anticipate the expected results by specifying the purpose of the study. The teacher should be aware of the following rules when teaching: First rule: involvement of whole team members into work. The main purpose of this method is to involve students in all cognition. Second rule: Psychological preparation of students to work on this method. Participants should be encouraged and encouraged to do various exercises and to share some of their learning experiences in the classroom. Third rule. It is advisable not to have a large number of students. Each participant should be able to express his point of view. The fourth rule. Required place of work. That is, the pupils will be provided with the opportunity to move freely for a group, for a couple to change places. Preliminary consideration of the free and comfortable mobility of the participants to choose each other, board, computer, visual work. Fifth rule. Careful attitudes toward pupils in grouping issues. The first step is to allow participants to voluntarily separate. Organization of collective and design research: Creation of a genuine interconnection environment through the formation 
of common values and principles, common good traditions of collaborative process participants; become a situation where individual pupils and staff will be able to adopt and introduce innovative methods, advanced research projects, and work without psychological-pedagogical experience, problem-free research; humanistic, democratic trends, diagnostic techniques, subject to subject relationships, and communication between pupils and teachers, pupils and pupils, teachers and parents, have a new character as an interactive, reflexive, collective unit (Yermentaeyeva, et al., 2014).

Research-based learning relies on the theory of constructivism. When using this approach, pupils ask themselves questions, they do not just present facts with the facilitator, the facilitator, the facilitator, and explore the issues by developing the appropriate scenario. Pupils choose the research question and the way they respond to this question (Petrovsky, 1996).

\section{Role of a teacher in active learning}

The purpose of the primary education program is to avoid negligent teachers, even though students are free to think (Marzhan, et al., 2014). That is why pupils set up their own fortress from the point where they have reached certain successes to their nearest development zone. Students need support when they work. Teachers, independent experts, worksheets, books or other sources, can provide such support. According to this principle, the student should strive to learn more at the lesson than he / she achieves at individual learning. Therefore, we recommend the following algorithm for research.

Learners are motivated by the idea that learners are more likely to learn in the lesson rather than work alone (teacher support). For example, identifying and involving students in the task selection process increases the degree of their learning in the learning process, as they are supervised by a certain degree of research. The process of coordination of research in primary school should be conducted with the help of the teacher (Tashkenbayevna et al., 2018). For example, teachers can help categorize pupils' questions as follows: It is interesting to know, I want to know, it is important to understand the underlying theme. This classification system can be used to help pupil's select future research questions. In particular, the teacher should ensure that only questions relevant to the objectives of the curriculum need to be addressed in order to avoid mismatched questions.

\section{Conclusion}

Theoretical basis of preparation of pupils to research activity was taken on the principles of humanity and theories about the essence and content of cognitive research activities in philosophical, psychological and pedagogical literature were studied. Experimental and scientifically methodical support of the experimental conclusion has been accomplished in the formulation of theoretical principles on the problem, creation of a set of program and methodical tools for their implementation. Teachers' research and methodological recommendations have been put into practice for the preparation of students for research activities.

Research-based learning relies on the theory of constructivism. Pupils use their resources to study the themes and make their own conclusions. This will help you to build up your skills and acquire a deeper level of knowledge that is essential to understanding the subject. Usually, research-based learning is linked to the subject of "natural science" in elementary grades, but it can serve as a basis for any subject, and it is perfectly suited for social issues such as outlook.

Scientific literature describes three basic approaches to teaching and learning based on research. These three approaches can be summarized as follows: Structured research. The teacher explains in detail the approaches that students follow (by describing each step). Learners are expected to comment, discuss and summarize the issue based on what they find (or someone else). The study under the teacher's guidance. The teacher offers a certain structure that students adhere to (for example, selecting a question that you are researching from a list of questions). Pupils can choose the approach to answer questions.

The teacher mainly supports the structured research. It is therefore advisable to use this approach for elementary classes or for new skills or lessons learned. When pupils grow and experience is full, the 3rd grade classroom teacher can use the study. The primary objective of primary school pupils is to successfully conduct an open study that aims to develop higher level thinking skills. The study based on research within the educational program for primary grades is a powerful pedagogical tool that adheres to the principles of active learning. It can also be an effective environment where students can discuss, create, and analyze arguments. However, this is not the only pedagogical approach that can be used to study openly. The study-based learning method can be used in any subject. If the main subject of the 
discipline is study, the teacher will be transferred to the assistant and the student will be the main actor.

\section{Acknowledgments}

The authors would like to thank everyone who contributed to this article.

\section{Conflict of interests}

The authors declare no conflict of interest.

\section{References}

Akoul, M., Lotfi, S., \& Radid, M. (2020). Effects of academic results on the perception of competence and self-esteem in students' training. Global Journal of Guidance and Counseling in Schools: Current Perspectives, 10(1), 12-22. https:// doi.org/10.18844/gjgc.v10i1.4874

Bakhtin, M. M. (1979). Art and answerability (M. Holquist, Ed.; V. Liapunov, Ed. \& Transl.). Austin, TX: University of Texas Press. https://tr.wikipedia.org/wiki/Mihail_Bahtin

Khusainova, S. V., Matveyeva, L. V., Ermilova, L. P., Yakushevskaya, K. N., Kolomiychenko, L. V., \& Mashkin, N. A. (2018). Adaptive model of psychological and pedagogical accompany of student professional training. Revista ESPACIOS, 39(05). https://www.revistaespacios.com/a18v39n05/18390522.html

Khusainova R., de Jong A., Lee N., Marshall G. W., Rudd J. M. (2020). Salesperson Intrinsic and Extrinsic Motivation Revisited: A Combinatory Perspective: An Abstract. In: Wu S., Pantoja F., Krey N. (eds) Marketing Opportunities and Challenges in a Changing Global Marketplace. AMSAC 2019. Developments in Marketing Science: Proceedings of the Academy of Marketing Science. Springer, Cham. https://doi.org/10.1007/978-3-030-39165-2_54

Lopes, V. P., Rodrigues, L. P., Maia, J. A., \& Malina, R. M. (2011). Motor coordination as predictor of physical activity in childhood. Scandinavian journal of medicine \& science in sports, 21(5), 663-669. https://doi.org/10.1111/j.16000838.2009.01027.x

Marzhan, D., Gulzhan, S., Ayakoz, T., Marzhan, K., \& Elmira, U. (2014). The formation of the primary school pupils'combining accounting skills relaying to a multiplying. Procedia-Social and Behavioral Sciences, 136, 396-399. https://doi. org/10.1016/j.sbspro.2014.05.347

Nefedchenko, O. I. (2018). Foreign and native scientists about the ideas and techniques of heuristic education. Pedagogy and Psychology, 41. http://doi.org/10.31174/SEND-PP2018-164VI68-10

Ozcan, D., \& Genc, Z. (2016). Pedagogical Formation Education via Distance Education. Eurasia Journal of Mathematics, Science \& Technology Education, 12(2). https://doi.org/10.12973/eurasia.2016.1205a

Petrovsky, V. A. (1996). Lichnost'v psihologii. Paradigma subektnosti [Personality in psychology. Paradigm of subject]. Rostovna-Donu: Izdvo «Phoenix.

Read, T. (2020). Towards a new model for inclusive education based on virtual social inclusion and mobile openness. World Journal on Educational Technology: Current Issues, 12(1), 14-22. Retrieved from https://un-pub.eu/ojs/index.php/wjet/ article/view/4507

Roth, W. M. (2014). Reading activity, consciousness, personality dialectically: Cultural-historical activity theory and the centrality of society. Mind, Culture, and Activity, 21(1), 4-20. https://doi.org/10.1080/10749039.2013.771368

Ryndak, V. G., \& Saldaeva, O. V. (2019). The revival of values and meanings of the teacher education: Reflexive-creative approach. Cypriot Journal of Educational Sciences, 14(2), 266-277. https://doi.org/10.18844/cjes.v14i2.4239

Talyzina, N. F. (1974-1975). Psychological foundations of programed instruction. Bulletin de Psychologie, 28(7-8), 439-458. Retrieved from https://psycnet.apa.org/record/1975-24137-001

Tashkenbayevna, N., Kenesbaev, S. M., Zhailauova, M. K., Elmira, U., Nurzhanova, S. A., \& Stambekova, A. S. (2018). Possibilities of the Subject 'Information and Communication Technologies' in Accustoming Primary School Students to Research Activities. International Journal of Interactive Mobile Technologies (iJIM), 12(6), 35-46. https://doi. org/10.3991/ijim.v12i6.9622

Turalbayeva, A. T., Sultanbek, M., Utyupova, C. E., Aidarov, B. Z., Uaidullakyzy, E., Zhumash, Z., \& Uzunboylu, H. (2017). The general preparation of the training of elementary school and the family and the education of gifted children school in cooperation principles. Ponte, 73(4), 239-251. https://doi.org/10.21506/J.PONTE.2017.4.54

Turculet, A., \& Voinea, M. (2019). Teamwork between class teachers and support teachers as the basis of inclusion-A case study in Romanian primary school education. New Trends and Issues Proceedings on Humanities and Social Sciences, 6(1), 328-335. https://doi.org/10.18844/prosoc.v6i1.4185

Yermentaeyeva, A., Aurenova, M. D., Uaidullakyzy, E., Ayapbergenova, A., \& Muldabekova, K. (2014). Social intelligence as a condition for the development of communicative competence of the future teachers. Procedia-Social and Behavioral Sciences, 116, 4758-4763. https://doi.org/10.1016/j.sbspro.2014.01.1021

Yildirim, A., \& Simsek, H. (2008). Sosyal Bilimlerde Nitel Arastirma Yöntemleri [Yildirim, A. and Simsek, H. (2008) Sosyal Bilimlerde Nitel Arastirma Yöntemleri. Seçkin Yayincilik.]. Seçkin Yayincilik. 